\title{
DIALÉTICA DO OLHAR NO POEMA O NAVIO NEGREIRO DE CASTRO ALVES
}

Artur Bispo dos Santos Neto

\begin{abstract}
RESUMO: O desenvolvimento do poema $O$ navio negreiro revela a pertinência da interpretação benjaminiana da alegoria como categoria-chave para entender as contradições do mundo. A vivência do choque e da ruptura é o cerne dessa tragédia no mar, em que o poeta reveste as palavras com os contornos das imagens alegóricas. No poema assistimos dançar a serpente, o chicote, as correntes, as bandeiras, o barco nas ondas do mar e a multidão dos escravos. O poeta toma o partido das vitímas da narrativa e mostra as marcas do sofrimento do outro, daquele que é silenciado pela história oficial. Isso é possível porque o olhar do poeta é dialético, é um olhar oblíquo, que reconstrói as coisas sob diferentes ângulos.
\end{abstract}

PALAVRAS-CHAVE: Olhar, alegoria, escravo, dialética, obliquo.

ABSTRACT: The development of the $O$ navio negreiro(The slave ship) poem reveals the allegory benjaminian interpretation pertinence as key-category to understand the contradictions of the world. The shock and the rupture experience is the core of this sea tragedy, which the poet overlays the words with the bounds of the allegoric images. In the poem we watch the snake dance, the horsewhip, the chains, the flags, the boat on sea waves and the slave crowd. The poet takes the narrative victims party and shows the suffering marks of the other one, that one that is silenced by the official history. This is possible because the poet look is dialectic, is a oblique look, that rebuilds the things under different angles.

KEYWORDS: Look, allegory, slave, dialectic, oblique.

Para navegar nas águas desse poema significativo no decurso do Romantismo brasileiro, tentamos suscitar uma interpretação do poema a partir do presente, procurando compreendê-lo como um texto literário da segunda metade do século XIX que fala ao homem do começo do século XXI. A interpretação desse poema possibilita não somente a compreensão das amarras e aporias do passado, mas também o entendimento das contradições do tempo presente; como afirma Walter Benjamin, partimos da premissa de 
que: "Não se trata de apresentar as obras literárias no contexto de seu tempo, mas de apresentar, no tempo em que elas nasceram, o tempo que as revela e conhece: o nosso". ${ }^{1}$ Ao lançarmos luzes sobre o passado que envolve e acalenta o poema em discussão, descobrimos uma constelação que serve para iluminar o nosso tempo. Esta perspectiva teórica permite entender a moldura irregular da sua tessitura, bem como a natureza do método dialético que esclarece Benjamin: "Dizem que o método dialético visa fazer jus à situação histórica concreta do objeto estudado. Mas trata-se também de fazer jus à situação histórica concreta que suscita o interesse pelo objeto estudado". ${ }^{2}$ Para Adorno, "O que há de doloroso na dialética é a dor, elevada ao conceito, pela pobreza desse mundo". ${ }^{3} \mathrm{O}$ dilaceramento é o móbile desse poema tanto no trato do desenvolvimento do seu conteúdo quanto na apresentação imagética de sua forma. A dialética constitui-se como artefato óptico que permite que o sujeito lírico eleja a alegoria como categoria estético-filosófica fundamental para a compreensão da realidade. Para Benjamin, "a apoteose barroca é dialética. Ela se consuma no movimento entre extremos", ${ }^{4}$ em que a alegoria não é uma mera técnica de ilustração através de imagens, mas uma linguagem e uma escrita do modo como as coisas se configuram no mundo despedaçado. Vejamos como isso ocorre no desenvolvimento do poema $O$ navio negreiro de Castro Alves 5 .

\section{1) Dialética do olhar}

Partimos do entendimento que o texto poético é manifestação do sutil jogo que envolve os olhos e a boca, quer dizer, a visualidade e a sonoridade. Aquilo que a boca não consegue transmitir e os ouvidos não conseguem captar ela transfere para os olhos. Assim, o poeta consegue descrever imagens que ultrapassam os limites do código verbal. Os olhos constituem-se como elemento fortuito da captação e compreensão do mundo. Contra a concentração do saber fundada na racionalidade cartesiana, o Romantismo valorizou a dimensão sensível do conhecimento, especialmente a percepção sensível das coisas. Por

\footnotetext{
${ }^{1}$ Apud BOLLE, Willi. Fisiognomia da metrópole moderna: representação da história em Walter Benjamin. 2. ed. São Paulo: EDUSP, 2000, p. 47.

${ }^{2}$ Apud BOLLE, Willi. Fisiognomia da metrópole moderna: representação da história em Walter Benjamin. 2. ed. São Paulo: EDUSP, 2000, p. 73.

3 ADORNO, Theodor. Dialética negativa. Versión castellana de José Maria Ripalda. Madrid: Taurus Ediciones, 1986, p. 14.

${ }^{4}$ BENJAMIN, Walter. Origem do drama barroco alemão. Trad. Sergio P. Rouanet. São Paulo: Brasiliense, 1984, p. 182.

5 CASTRO, Alves. Obras completas. Edição organizada por Eugênio Gomes. 2. ed. Rio de Janeiro: Nova Aguilar, 2004, p. 277-284.
} 
outro lado, sem cair no dogmatismo do método empirista, a compreensão do mundo através da imaginação - que pensa o mundo através de imagens - pode ocorrer de maneira dialética, quer dizer, a configuração do mundo através das imagens pode revelar não somente suas rupturas, seus choques e suas contradições; mas também o movimento de aproximação e distanciamento, ambigüidade e multiplicidade de sentidos, empatia e diferença.

Na sua obra Charles Baudelaire um lírico no auge do capitalismo, Benjamin destaca a primazia do olho sobre o ouvido. No espaço topográfico da cidade moderna, onde as relações sociais são pautadas pelo ponteiro do relógio, a rapidez e o fluxo das coisas não permitem concentração, seja o repouso da meditação, seja atenção pormenorizada para a contemplação. Envolvido pela órbita da distração, o estado de coisas não colabora para o fortalecimento dos nexos de sociabilidade centrada na oralidade reiterada da narrativa e da história que passa de boca em boca. Na grande cidade, o ordenamento das coisas se presta muito mais ao olho do que ao ouvido, este último perdido no burburinho ensurdecedor das ruas e avenidas divididas entre pedestres e automóveis, galerias e passantes. O mundo moderno é por excelência um espaço de imagens, havendo nele um excesso de luz e claridade que conduz a uma nova espécie de cegueira. Nesse contexto, o advento da fotografia e do cinema revoluciona o mundo das artes e consegue expressar o modo de ser do homem moderno, que tem na vivência do choque sua lei fundamental. Para Benjamin, o mundo moderno é essencialmente um mundo de imagens e de sonhos; são elas que encantam o universo dos homens que fazem o coração da metrópole, em que as coisas aparecem não como realmente são, mas sob a roupagem fantasmagórica do mundo da alegoria.

A compreensão do mundo como algo que está em permanente trânsito revela-se no poema $O$ navio negreiro particularmente no movimento rápido da embargação que, como veleiro brigue, "corre à flor dos mares". O poeta denomina o navio de: "veleiro brigue", "naus errantes", "brigue à bolina", "brigue voador" e "brigue imundo". Esse navio é um veleiro brigue, quer dizer, é uma embarcação que estrutura suas velas na forma de três mastros. $\mathrm{O}$ ordenamento dessa equipagem é expressão da revolução espetacular sucedida entre os séculos XV e XVI. Aliada à descoberta do telescópio, da bússola, do quadrante e do astrolápio, a arte da navegação deu um salto significativo e encurtou as distâncias que 
separavam o continente europeu do resto do mundo. O poema inicia destacando a rapidez do veleiro, que esconde sua identidade.

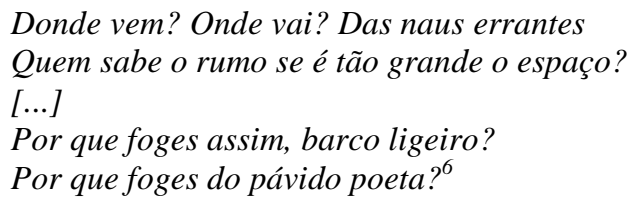

É mister destacar que a agilidade figura como a quintessência da vida moderna, em que, como dissemos, a existência do homem passa a ser orientada pelo tempo da fábrica. $\mathrm{O}$ tempo da produção e da circulação da mercadoria é fundamental no sistema capitalista. $\mathrm{O}$ alto grau de investimento financeiro na indústria naval portuguesa, feito pela burguesia e pelo Estado absolutista, será coroado pelo lucro rápido no comércio de especiarias e de escravos. No triângulo comercial entre América, Europa e África, as embarcações marítimas cumpriram um papel fundamental; da América levavam as riquezas naturais para o mundo europeu juntamente com o necessário para a prática do escambo nos portos africanos, e finalmente, a comercialização dos escravos nos cais brasileiros. A proibição do tráfico de escravo pela Inglaterra em 1807 fez com que os navios ganhassem maior agilidade à proporção que diminuíram de tamanho. A segunda parte do poema torna a registrar a rapidez do navio:

\section{Resvala o brigue à bolina Como um golfinho veloz. Presa ao mastro da mezena Saudosa bandeira acena Às vagas que deixa após.}

Nos versos acima o brigue é comparado com um golfinho e merece destaque pelas ondas deixadas como um "doido cometa". O brigue resvala no mar ao sabor das vagas devido a sua estruturação interna que permite deslizar nas águas do oceano rapidamente sem fazer qualquer gesto de afundamento nos abismos marítimos. A bolina garante esse movimento porque forma aquela parte principal da região inferior do veleiro, sendo composta duma chapa plana situada no casco da embarcação. Além da bolina, o poeta destaca outras partes do navio, como: tombadilho, velas, proa, mastro, gávea, pavilhão, cordas e bandeira.

O andamento do poema revela que as marcas deixadas para trás pelas espumas são tanto expressão da compulsão da força do barco sobre as águas quanto metáforas das

${ }^{6}$ CASTRO, Alves. Obras completas. Edição organizada por Eugênio Gomes. 2. ed. Rio de Janeiro: Nova Aguilar, 2004, p. 277. 
marcas da violência representadas pela escravidão, ainda desconhecida para o leitor no começo do poema. O movimento está presente não apenas no navio que corta o mar rapidamente, mas também na bandeira que acena: "E as vagas após ele correm ... cansam / Como turba de infantes inquieta". O movimento veloz ainda se revela no vôo do albatroz que sobe e desce, e nos chicotes que "voam mais e mais". A engenharia do navio que encanta pela sua velocidade faz o poeta descer das alturas: "Desce do espaço imenso, ó águia do oceano!/ Desce mais, inda mais... não pode olhar humano/ Como o teu mergulhar no brigue voador!". O navio voador torna-se objeto de decepção quando observado de perto. Ao debruçar-se sobre o estado de coisas que envolvem a interioridade do navio, a rapidez transforma-se em confusão e a pressa contrapõe-se ao estado de regressão temporal: "Presa nos elos de uma só cadeia/ A multidão faminta cambaleia".

Como um moderno, Castro Alves parece levar à mão uma máquina fotográfica, procurando captar a natureza das coisas de maneira minuciosa, pois: "A natureza que fala à câmara não é a mesma que fala ao olhar". ${ }^{7}$ Envolvido por essa preocupação ele reconstrói o mundo sob a representação pictórica do painel majestoso:

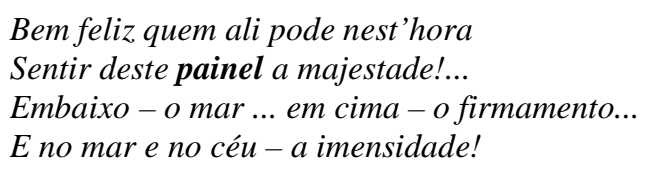

Parecido com um geômetra, Castro Alves sabe ordenar o espaço da trama que está para vir. Mediante o recuso do olhar em perspectiva, o poeta começa a apresentação e o desenvolvimento do assunto, descrevendo o painel paisagístico que domina a natureza. Esse painel será acrescido pelo quadro de amarguras que surge como um verdadeiro contraponto à imagem primeiramente exibida. As imagens são apresentadas como imagens dialéticas, porque elas, como dissemos, manifestam-se mediante o movimento de distanciamento e aproximação. É na forma de um pintor ou de um fotógrafo que o poeta descreve o mundo do navio negreiro:

\footnotetext{
Desce mais ... inda mais... não pode olhar humano

Como o teu mergulhar no brigue voador!

Mas que vejo eu aí... Que quadro d'amarguras!

É canto funeral! Que tétricas figuras!...

Que cena infame e vil... Meu Deus! Meu Deus! Que horror!
}

\footnotetext{
${ }^{7}$ BENJAMIN, Walter. Pequena história da fotografia. In. BENJAMIN, Walter. Magia e técnica: ensaios sobre literatura e história da cultura. Trad. Sérgio Paulo Rouanet. $7^{\text {a }}$ ed. São Paulo: Brasiliense, 1994, p. 94.
} 
Os versos revelam a primazia do olho nos termos sugeridos pelo próprio texto: olhar, quadro, vejo, figuras, cena. Primeiro, o poeta destaca a presença de um olhar que se choca com a cena apresentada; segundo, manifesta o olhar do poeta que insiste na percepção do objeto nele mesmo, com o rigor de um cientista social que pretende retirar dele os elementos capazes de interceptá-lo.

A afirmação da negação do universo das alturas como o espaço privilegiado para enxergar o mundo e conduzir a humanidade cai por terra nessa parte do poema, quando o sujeito lírico argumenta: "Desce mais... inda mais... não pode olhar humano/Como o teu mergulhar no brigue voador!" O poeta deve eliminar as distâncias, precisa descer das alturas para acompanhar o que se passa no navio, pois se ele continuar nas alturas não vai acompanhar o processo de transformação que se passa no mundo empírico. E, diga-se de passagem, essa transformação é muito rápida; o navio é um “brigue voador". Ao observar o que se passa na realidade o sujeito lírico assume uma posição crítica diante do estado de coisas que vigora no mundo. Essa posição demonstra que a poesia romântica não se limitou a uma posição de deleite e prazer da poesia nela mesma, pelo contrário, aponta que a poesia possui um vínculo essencial com a realidade. O poeta qualifica aquilo que vê como figuras tétricas: "Mas que vejo eu aí... Que quadro d'amarguras!/É canto funeral!... Que tétricas figuras!..."

O termo figura está relacionado às palavras: fingire, figulus, dictus e effigies. ${ }^{8}$ Embora não tenham a propriedade das coisas nelas mesmas, as figuras não são meras abstrações da consciência; são esfinges e são dictos. Apesar de não condensarem em si a corporeidade das coisas presentificadas, elas remetem para as coisas enquanto tais na forma de sombras, de representações fantasmais da matéria. Os escravos aparecem como figuras assustadoras cujo detalhamento será explicitado na quarta parte do poema:

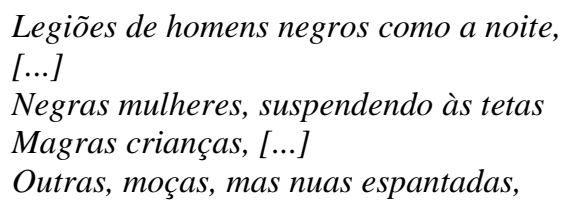

Castro Alves não escolhe a via mais curta para falar do tráfico negreiro, que fora extinto no plano externo brasileiro em 1850, mas que permanecia existindo no plano

\footnotetext{
${ }^{8}$ MORA, José Ferrater. Dicionário de filosofia. Trad. Roberto Leal Ferreira e Álvaro Cabral. São Paulo: Martins Fontes, 1996, p. 295.
} 
interno; pelo contrário, ele prefere sempre o caminho oblíquo, o itinerário das curvas e linhas tortas, como argüi Luiz Gama:

\author{
Quero também ser poeta, \\ Bem pouco, ou nada me importa \\ Se a minha veia é discreta, \\ Se a via que sigo é torta.
}

Podemos perceber a imagem sinuosa da espiral no próprio ordenamento imagético das estrofes que constituem os versos da quarta parte do poema. Esse ordenamento revela o mundo Barroco carregado de tensão e distensão, de altos e baixos, de sombra e luz. A alegoria barroca se manifesta na identificação e multiplicidade de sentido dos elementos. As correntes, o chicote, a multidão, a serpente, a escravidão, a bandeira e as manchas configuram-se como um mundo de dobras:

$$
\begin{gathered}
\text { No entanto o capitão manda a manobra, } \\
\text { E após, fitando o céu que desdobra } \\
\text { Tão puro sobre o mar, } \\
\text { Diz do fumo entre os densos nevoeiros: } \\
\text { "Vibrai rijo o chicote, marinheiros! } \\
\text { Fazei-os mais dançar!...” }
\end{gathered}
$$

O olhar em perspectiva do eu lírico permite a compreensão do mundo como um amontoado alegórico de dobras que se desdobram. Contrapondo-se à primeira parte do poema, aqui o céu se desdobra, quer dizer, mostra aquele lado que ainda não havia sido revelado. A desdobra é o outro da dobra. No poema em discussão aparecem dobras no céu e dobras no mar, dobras nos ventos e dobras nas águas, dobras nos barcos e dobras nos homens, dobras nas cordas e dobras nas velas, dobras nos corpos e dobras nas almas, dobras nas serpentes e dobras na multidão, dobras nas correntes e dobras nos chicotes. ${ }^{9} \mathrm{O}$ andar de cima do firmamento Barroco se confunde com o andar de baixo do firmamento para formar um painel pictórico. O poeta olha o mundo de vários ângulos: de cima, de baixo, de lado e junto. Existe um espaço dentro e um espaço fora do navio, por isso o poeta faz questão de destacar que o navio deixa "vagas" por onde passa. Para Benjamin, o naturalismo barroco "é a arte das menores distâncias... Em todos os casos, os instrumentos naturalistas visam o encurtamento das distâncias...". ${ }^{10}$ Os dois mundos, geralmente considerados como cindidos, acabam se comunicando nas dobras do espírito e nas dobras

\footnotetext{
${ }^{9}$ DELEUZE, Gilles. A dobra: Leibniz e o barroco. Trad. Luiz Orlandi. 2. ed. Campinas: Papirus, 1991, p. 15.

${ }^{10}$ BENJAMIN, Walter. Origem do drama barroco alemão, p. 90.
} 
da matéria. $\mathrm{O}$ espaço aberto do mundo, que podia ser comparado com o espaço aberto do espírito livre do homem, é dobrado e substituído pelo espaço cósmico de horror:

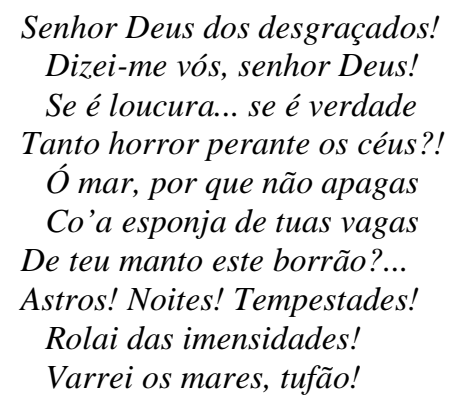

Castro Alves recorre à esponja, a essa matéria de textura infinitamente porosa, para apagar as manchas que a escravidão deixa sobre o mar. A esponja é um objeto que serve de metáfora da necessidade de limpeza e da depuração dos espaços sujos que existem no mundo. A esponja deve servir para apagar as "vagas" da escravidão deixadas pelo navio - o termo "vaga" aparece dez vezes, sem falar nos termos correlatos como ondas, traços, esteira, etc. Diferentemente do senso comum que prefere estacionar nos limites da linha reta, não entendendo o ordenamento oblíquo e sinuoso das coisas, o poema revela a primazia das dobras, pois é na curvatura do círculo que o céu e o mar se articulam e se enlaçam num "abraço insano". É insano o abraço desses elementos porque o encontro produz não apenas beleza, mas também a sensação de choque presente naquilo que se apresenta grotesco e impossível de ser entendido logicamente pela própria imaginação. O oceano é uma dobra que se desdobra em muitas ondas, mimetizando o caudal sinuoso da serpente que desliza no espaço cósmico do mar até encontrar a praia com seus infinitos grãos de areia. Assim, o traçado de dobras que envolvem o mar se contrapõe ao universo fragmentado dos grãos de areia que formam o deserto:

$$
\begin{aligned}
& \text { Depois, o areal extenso... } \\
& \text { Depois, o oceano de pó. } \\
& \text { Depois no horizonte imenso } \\
& \text { Desertos... desertos só... } \\
& \text { E a fome, o cansaço, a sede.. }
\end{aligned}
$$

O pó de areia é o mundo dos fragmentos da alegoria, são as partículas irregulares do turbilhão da linguagem após a queda da torre de Babel, como afirma Benjamin, em que os homens não conseguem mais se entender. É a expressão da decomposição e da ruína como princípio que rege todos os seres vivos. Ao invés do preceito da harmonia celestial, o mundo dos homens é ordenado pela colisão de forças e interesses, pela multiplicidade de 
sentidos que faz com que a multidão seja tanto sinuosa quanto fragmentada. A multidão vive sob o horror da unidade imposta pela autoridade do chicote.

\section{2) O navio negreiro como poema dramático ou a dialética do tempo}

O movimento em espiral de dobras que se desdobram constitui tanto o movimento das figuras representadas quanto o movimento da história. Assim como o espaço do navio negreiro que não é linear, mas de dobras que se desdobram, o tempo nessa epopéia de horror não é linear e homogêneo, mas um tempo marcado de rupturas e quedas. A história e a literatura dominante não conseguem esconder nas suas interrupções e nos seus silêncios o grito de sofrimento dos homens do porão. Para Benjamin, a verdade da narração não deve ser buscada na linearidade da trama, mas naquilo que lhe escapa, nos seus tropeços e nos seus silêncios, pois é nos tropeços e nos silêncios da narrativa dos vencedores que a verdade se revela como um relâmpago, como um flash de luz.

Os elementos estruturadores do drama barroco (Trauerspiel) são reconfigurados na Tragédia do mar através dos termos: orquestra (coro), capitão (tirano), escravo (martírio), dança (personagens em cena), tombadilho (palco). Como dramaturgo, Castro Alves foi educado nos bastidores do teatro e escreveu o drama Gonzaga ou a revolução em Minas. A própria linguagem do poema castroalvino denota a presença da catástrofe e da ruína no seu interior: roto, extingue, arranca, guerra, mortalha, funeral, pélago, tempestade, tufão, lúgubre etc. Embora não conte com personagens em ação dialógica o poema sugere dramaticidade, existe a presença de figuras que dançam e revelam ação na descrição do sujeito lírico. Como no drama barroco, o poeta constrói um estilo lingüístico à altura da violência dos acontecimentos históricos relacionados ao tráfico de escravos da África para o Brasil.

O Romantismo preserva elementos do espetáculo lúdico Barroco quando, escreve Benjamin, "em face de uma preocupação intensa com o absoluto, a própria vida perdeu sua seriedade última". ${ }^{11}$ O navio negreiro é uma tragédia no mar, como indica seu subtítulo, no sentido moderno, pois ele tanto provoca o luto quanto descreve o estado de luto das criaturas. É um poema em que as figuras representadas brincam com a morte através do riso sarcástico de satanás, do riso irônico da orquestra e do riso cético do próprio escravo. Como

\footnotetext{
${ }^{11}$ BENJAMIN, Walter. Origem do drama barroco alemão, p. 105.
} 
no drama barroco, o elemento lúdico perpassa o poema, que começa destacando o movimento dos dois infinitos, como num jogo de crianças e culmina com a morte, como "Sansão, cego, caminha brincando, até seu túmulo". ${ }^{12}$ Os escravos zombam da morte de maneira similar: "E assim zombando da morte,/ Dança lúgubre coorte/ Ao som do açoite... Irrisão!...”.

O cerne da concepção barroca é a natureza do tempo como espaço do sofrimento humano, em que quanto maior a significação tanto maior a sujeição à morte. Como escreve Benjamin:

\begin{abstract}
A história em tudo o que nela desde o início é prematuro, sofrido e malogrado, se exprime num rosto - não, numa caveira. (...). Nisso consiste o cerne da visão alegórica: a exposição barroca, mundana, da história como história mundial do sofrimento, significativa apenas nos episódios do declínio. Quanto maior a significação, tanto maior a sujeição à morte, porque é a morte que grava mais profundamente a tortuosa linha de demarcação entre a physis e a significação (...). A significação e a morte amadureceram juntos no curso do desenvolvimento histórico, da mesma forma que interagiam, como sementes, na condição pecaminosa da criatura, anterior à Graça. ${ }^{13}$
\end{abstract}

A dialética na imobilidade é o princípio constitutivo da alegoria; nela, a significação e a morte amadurecem juntas. Para os autores barrocos, a alegoria é uma figura emblemática que serve para tipificar a natureza dilacerada e catastrófica do mundo humano. A alegoria revela a antinomia das coisas, em que "cada pessoa, cada coisa, cada relação pode significar qualquer outra". ${ }^{14}$ A ambigüidade e a multiplicidade são as marcas essenciais da concepção alegórica, em que a ambigüidade não passa da "riqueza do desperdício". ${ }^{15}$ A marca da alegoria é o distanciamento das coisas do seu sentido original, é a alienação das coisas da sua verdadeira essencialidade, à medida que allo-agorein significa dizer outra coisa; ela é a afirmação da diferença sem qualquer perspectiva de reconciliação. A substituição do simbólico pela alegoria é seguida pela alienação das coisas em relação ao seu si mesmo. Enquanto o símbolo indica a busca da pureza de significação através de uma evidência de sentido, a alegoria afirma um abismo entre o sentido das coisas e as próprias coisas, ela nasce e renasce da fuga perpétua de um sentido último.

No universo da alegoria não existe mais ponto fixo e imutável, nem no objeto, nem no sujeito da interpretação alegórica, que garanta a verdade do conhecimento. A

\footnotetext{
${ }^{12}$ BENJAMIN, Walter. Origem do drama barroco alemão, p. 90, p. 106.

${ }^{13}$ BENJAMIN, Walter. Origem do drama barroco alemão, p. 188.

${ }^{14}$ BENJAMIN, Walter. Origem do drama barroco alemão, p. 198.

${ }^{15}$ BENJAMIN, Walter. Origem do drama barroco alemão, p.199.
} 
ambigüidade e multiplicidade de sentidos se manifesta no poema em vários momentos, entre eles destacamos:

$$
\begin{gathered}
\text { No entanto o capitão manda a manobra, } \\
\text { E após, fitando o céu que se desdobra } \\
\text { Tão puro sobre o mar }
\end{gathered}
$$

Existe um transbordar de sentido no termo manobra. A manobra a que se refere o verso não é apenas a manobra do navio sobre o mar, que é própria de quem possui a patente de capitão. A manobra aqui não tem também uma dimensão meramente técnica, mas uma conotação política, quer dizer, é a manobra de quem tem o poder de mando:

\section{Diz do fumo entre os densos nevoeiros: \\ "Vibrai rijo o chicote, marinheiros! Fazei-os mais dançar!...”}

É próprio das classes dominantes construírem a história mediante o artifício da manobra política. E no momento em que tramam contra os dominados e ordenam a carnificina violenta, procuram desviar seu olhar do curso das coisas, "fitando o céu que se desdobra". Ao olhar para o alto, ele tenta dirimir-se do peso da responsabilidade moral perante o palco de atrocidades ordenadas.

Os densos nevoeiros são fundamentais porque impedem tanto enxergar a si mesmo quanto enxergar os outros como iguais. Os densos nevoeiros servem também para encobrir a face do tirano e impedir que ele possa olhar face a face suas vítimas. Para não vacilar na sua decisão, o tirano olha para "o céu que se desdobra/ Tão puro sobre o mar", pois um capitão que vacila não está apto para a manobra técnica e política do navio. O tirano é aquele que garante o poder na embarcação como se fosse a inexorável lei de ferro da natureza.

O sucesso da empreitada exige a divisão social dos papéis no interior do navio: há aquele que ordena e existem aqueles que obedecem, com isso a responsabilidade perante a tortura e o genocídio se dissipa no nevoeiro da burocracia do poder. O nevoeiro impede também que as vítimas possam identificar os seus torturadores e aqueles que ordenam a barbárie. Todo esse espaçamento opaco e coberto de densos nevoeiros colabora na elaboração da violência, conduzindo ao sucesso da empreitada, e sustenta tanto o riso da orquestra quanto o riso de Satanás.

Convicto do intervalo existente entre a condição efetiva de catástrofe vivenciada pelo escravo e a capacidade descritiva do texto literário o poeta recorre às pausas, às 
aliterações, às reticências, como se através de cada um desses recursos a voz do outro pudesse eclodir de maneira mais significativa. As reticências servem como espaço em branco no poema; por meio delas o leitor pode imaginar o suspiro do escravo, começando com a descrição da dança que mostra os homens como legiões: "Horrendos a dançar..."; o suspiro do velho e os gritos: "Se o velho arqueja, se no chão resvala, /Ouvem-se gritos... o chicote estala./ E voam mais e mais..."; o riso da orquestra: "irônica, estridente..."; as sombras e os gritos: "Gritos, ais, maldições, preces ressoam! E ri-se Satanás!...”; e assim cai o escravo “p'ra não mais s'erguer!...”. São cinqüenta e quatro reticências que aparecem nos duzentos e quarenta versos que compõem o poema (mais de vinte por cento deles).

Ao contrário da concepção positivista que entende a história numa perspectiva progressiva, em que prevalece a noção de tempo linear, percebe-se um movimento diacrônico do tempo, pois, no entendimento do poeta, acerca dos homens do tombadilho, a história se inscreve como retrocesso. A contradição entre liberdade e escravidão aparece como relacionada a dois espaços topográficos distintos: África e porão do navio:

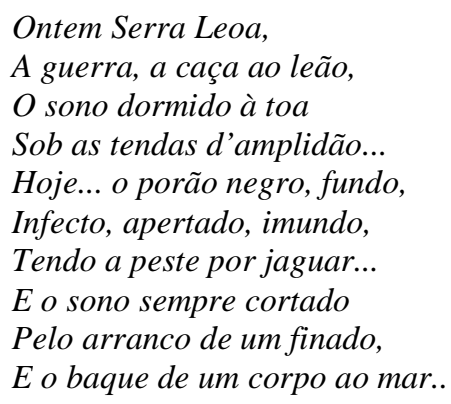

O poeta olha para a história e o que vê crescer à sua frente é um amontoado de escombros: "Dizei-me, Senhor Deus!/ Se eu deliro... ou se é verdade/ Tanto horror perante os céus?!”. A pergunta aqui se confunde com o estado de espanto do sujeito lírico. E como o anjo da história benjaminiano, o poeta gostaria de apagar a paisagem de horrores e ruínas do mar da história. Por outro lado, o vento da história o impele a olhar para frente, para o futuro da humanidade e acalentar a doce ilusão de que a nova página será construída pelos heróis do novo mundo: “Andrada! Arranca este pendão dos ares!/ Colombo! Fecha a porta de teus mares!”.

\section{3) As imagens oníricas no poema $O$ navio negreiro de Castro Alves}

No espaço do sono ocorre uma dispersão de sentido, como ocorre uma explosão de gestos e de gritos nas imagens: "sonho dantesco", moças "espantadas", "turbilhão de 
espectros" "ronda fantástica", "densos nevoeiros", "noite confusa". Essas são as peças fundamentais do drama moderno, tudo é dominado pelo traço do espectro e do fantasmagórico. O drama moderno (Trauerspiel), como afirma Benjamin, é um espetáculo de enlutados e "para enlutados". ${ }^{16}$ A palavra espectro vem de spectrum, que quer dizer o mesmo que aparição, visão irreal do mundo, fantasma, figura imaginativa. Espectro remete a uma série de outras palavras, como aponta Lima:

Speculum - espelho; spectabilis - o visivel; specimem - a prova; o indício, o argumento e o presente; speculum é parente de spetaculum (a festa pública), que se oferece ao spectator (o que vê, o espectador), que não apenas se vê no espelho e vê o espectáculo, mas ainda pode voltar-se para o speculandus (a especular, a investigar, a examinar, a vigiar, a espiar) e ficar em speculatio (sentinela, vigia, estar de observação, pensar vendo) porque exerce a spectio (a vista, inspecção pelos olhos, leitura dos agouros) e é capaz de distinguir entre as species e o spectrum (espectro, fantasma, aparição, visão irreal. ${ }^{17}$.

$\mathrm{Na}$ perspectiva da tessitura desse poema, o sujeito lírico é o espectador do espetáculo (spetaculum) de espectros que se manifestam diante dos seus olhos como se fosse num espelho (speculum). Mediante a sua escritura o poeta oferece ao leitorespectador um conjunto de espectros que ele mesmo especula (speculandus) como spetaculum de horror. O poema se oferece ao leitor como um spectabilis (visível) de espectros horrendos a dançar.

As imagens em movimento são aparições espectrais, que são e não são aquilo que parecem ser. Esse movimento efêmero das figuras revela o estado de vacuidade do espetáculo barroco do mundo. Os espectros são figuras sombrias e noturnas. No Romantismo, a noite desempenha um papel fundamental, pois é no espaço das sombras que os fantasmas aparecem e as portas do inferno se abrem. Segundo Candido, "Os românticos foram sensíveis à força transfiguradora da noite, inclusive e sobretudo como hora do sonho, que eles fazem refluir sobre a realidade, provocando uma transmutação da maneira de ver e conceber tanto o mundo exterior quanto o mundo interior". ${ }^{18} \mathrm{O}$ Romantismo valorizou a noite pela sua relação com o ser lutuoso e melancólico. E a noite não é somente a hora dos espectros assustadores e grotescos, ela é também a hora oportuna para a prática dos crimes e das perversões. À noite se liga ao sono, ao mundo do sobrenatural e dos mistérios.

\footnotetext{
${ }^{16}$ I BENJAMIN, Walter. Origem do drama barroco alemão, p. 142.

${ }^{17}$ LIMA, Walter Matias. Notas introdutórias para discutir a história do corpo. Texto apresentado nas aulas da parte flexível nas graduações da UFAL. Maceió: texto digitado, em 2004, p. 3.

${ }^{18}$ CANDIDO, Antonio. Na sala de aula: cadernos de análise literária. São Paulo: Ática, 1985, p. 46.
} 
Os escravos vêm à baila no navio "voador" como criaturas deformadas que emergem do mundo dos mortos. As figuras são imagens estereotipadas das coisas. Na alegoria da caverna de Platão, as sombras são cópias imperfeitas do mundo verdadeiro, elas pertencem ao mundo dos simulacros. ${ }^{19} \mathrm{O}$ cenário carregado de sombras e espectros é tão catastrófico, que o sujeito lírico da narrativa descritiva interpela e indaga:

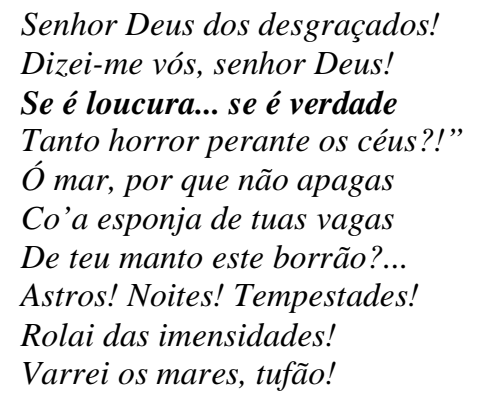

O estado das coisas leva o sujeito lírico a questionar o quadro que aparece. Como um filósofo cartesiano o poeta parece questionar o conhecimento advindo da percepção sensível, haja vista que os sentidos podem enganar. Esse questionamento relembra a atitude de Hamlet ante a aparição do espectro de seu pai, que surge noturnamente para esclarecer o episódio fatídico. Ao invés de acreditar no espectro, Hamlet prefere ele mesmo investigar o estado das coisas para chegar a uma conclusão. Em $O$ navio negreiro, a dúvida parece mais um instrumento maiêutico do que propriamente um procedimento cartesiano, porque na cena seguinte o poeta já busca um encaminhamento, pelo âmbito da percepção sensível, para a resolução do problema destacado. O olhar do poeta é convocado a ir além dos limites impostos pelo pesadelo do quadro de amarguras, mediante a força do despertar.

O espaço onírico é o espaço da confusão e da incerteza. A consciência humana não consegue afirmar nada sem cair nos pélagos, nas tempestades, nas vagas e nos abismos do oceano. O mundo onírico é o oposto da vida diurna que exige o despertar. O navio negreiro constitui-se como o reinado de sombras em contraposição ao espaço aberto e claro do céu dominado pelo Sol e pela Lua, pelos astros e pelas estrelas. O Barroco constitui-se como um jogo de luzes: ele brinca com o claro-escuro e com a multiplicidade das imagens e dos sentidos. Na linguagem do poema destacamos a presença de termos que mostram o jogo de luz e sombra: "dourada borboleta", "astros saltam", "acende as ardentias", "dourados", "lavas de vulcão", "brilho", "apagas”, "estrela se cala”, "luz", "luz do sol”, "noite”, "quadro de amarguras", "canto funeral", "tétricas figuras", "cena infame", "sonho

\footnotetext{
${ }^{19}$ PLATÃo. A república. Trad. Enrico Corvisieri. São Paulo: Nova Cultural, 1999.
} 
dantesco", "homens negros como a noite", "bocas pretas", "as sombras voam", "noite confusa", "cisma da noite nos véus..." etc. Diante do mundo das sombras, o céu emerge como topos ideal do Romantismo. É nele que emana a luz do Sol e "as promessas divinas da esperança...".

A condição dos escravos no tombadilho se inscreve como um fenômeno esquizóide. O que aparece diante dos olhos é difícil de distinguir, pois "agora você vê, agora você não vê". ${ }^{20}$ A visão, como afirma Benjamin, não tem certeza de nada, o brilho se extingue, "o eidos se apaga, o símile se dissolve, o cosmo inteiro se resseca". ${ }^{21}$ Assim, a alegoria imita as operações niveladoras e de equivalência da mercadoria e, ao fazê-lo, libera o objeto para uma nova polivalência de significados. Como na alegoria, o sentido dos objetos está sempre em outra parte. O valor do homem escravizado está sempre num outro lugar e nunca nele mesmo. O caráter fantasmal dos homens no palco dantesco do tombadilho do navio mimetiza o caráter fantasmal das coisas no sistema sócioeconômico em que tudo é regulado pelo preceito da mercadoria.

O mundo de imagens oníricas expressa o mal-estar da civilização burguesa que postulava o "Esclarecimento" (Aufklärung) como itinerário para a humanidade. O poema castroalvino aponta o distanciamento do ordenamento do mundo da lógica racional iluminista para a lógica da irracionalidade do comércio de seres humanos. O mundo das imagens fantasmagóricas alude ao caráter alienado que os homens assumem na sociedade capitalista, em que tudo aparece como deslocado do seu lugar, num outro que não é ele mesmo - como postula os elementos da ambigüidade e multiplicidades de sentidos presentes na categoria estético-filosófica da alegoria benjaminiana. A existência refratada dos escravos faz tudo parecer um grande palco em que todos aparecem como figurantes, representando existências que não são suas, mas de um outro que os refrata: o senhor. $\mathrm{O}$ escravo tem um existência distanciada de si mesmo, vive num outro que não ele mesmo.

A imagem d'O navio negreiro reconfigura-se no tempo presente; nele, o espaço imundo com suas figuras tétricas continua subsistindo no interior do universo topográfico urbano, oposição muito bem explorada por Walter Benjamin no seu ensaio Charles Baudelaire um lírico no auge do capitalismo. As contradições e ambigüidades do navio negreiro reaparecem no topos da metrópole contemporânea: matizada na oposição entre o

${ }^{20}$ EAGLETON, Terry. A ideologia da estética. Trad. Mauro Sá Rego Costa. Rio de Janeiro: Jorge Zahar Ed., 1993, p. 155.

${ }^{21}$ BENJAMIN, Walter. Origem do drama barroco alemão, p. 198. 
espaço iluminado dos shoppings centers e o espaço sombrio das favelas. O que serve para denotar a atualidade da temática desenvolvida nesse poema escrito na segunda metade do século XIX.

\section{REFERÊNCIAS BIBLIOGRÁFICAS}

ADORNO, Theodor. Dialética negativa. Versión castellana de José Maria Ripalda. Madrid: Taurus Ediciones, 1986, 409 páginas.

BENJAMIN, Walter. Origem do drama barroco alemão. Trad. Sergio P. Rouanet. São Paulo: Brasiliense, 1984, 276 páginas.

BENJAMIN, Walter. Pequena história da fotografia. In. BENJAMIN, Walter. Magia e técnica: ensaios sobre literatura e história da cultura. Trad. Sérgio Paulo Rouanet. 7. ed. São Paulo: Brasiliense, 1994, 253 páginas. - (Obras escolhidas; v. 1)

BENJAMIN, Walter. Charles Baudelaire um lírico no auge do capitalismo. Trad. José Martins Barbosa, Hemerson Alves Baptista. São Paulo: Brasiliense, 1989, 271 páginas. (Obras escolhidas; v. 3)

BOLLE, Willi. Fisiognomia da metrópole moderna: representação da história em Walter Benjamin. 2. ed. São Paulo: EDUSP, 2000, 426 páginas.

CANDIDO, Antonio. Na sala de aula: cadernos de análise literária. São Paulo: Ática, 1985, 88 páginas.

CASTRO, Alves. Obras completas. Edição organizada por Eugênio Gomes. 2. ed. Rio de Janeiro: Nova Aguilar, 2004, 906 páginas.

DELEUZE, Gilles. A dobra: Leibniz e o barroco. Trad. Luiz Orlandi. 2. ed. Campinas: Papirus, 1991.

EAGLETON, Terry. A ideologia da estética. Trad. Mauro Sá Rego Costa. Rio de Janeiro: Jorge Zahar Ed., 1993, 327 páginas.

GULLAR, Ferreira. Barroco: olhar e vertigem. In. NOVAES, Adauto (Org.). O olhar. São Paulo: Companhia das Letras, 1988, 478 páginas.

LIMA, Walter Matias. Notas introdutórias para discutir a história do corpo. Texto apresentado nas aulas da parte flexível nas graduações da UFAL. Maceió: texto digitado, em 2004, 21 páginas.

MORA, José Ferrater. Dicionário de filosofia. Trad. Roberto Leal Ferreira e Álvaro Cabral. São Paulo: Martins Fontes, 1996, 733 páginas. 
PLATÃO. A república. Trad. Enrico Corvisieri. São Paulo: Nova Cultural, 1999, 352 páginas.

SHAKESPEARE, William. Hamlet, príncipe da Dinamarca. Trad. F. Carlos de Almeida C Medeiros e Oscar Mendes. São Paulo: Abril Cultural, 1979, 447 páginas. 